\title{
Use of coconut fibre reinforced concrete and coconut-fibre ropes for seismic-resistant construction
}

\author{
Majid Ali $\bowtie$ \\ Department of Civil Engineering, Capital University of Science and Technology, (Islamabad, Pakistan) \\ $\triangle$ drmajidali15@gmail.com
}

\author{
Received 5 February 2015 \\ Accepted 21 May 2015 \\ Available on line 15 january 2016
}

\begin{abstract}
Earthquake-resistant and economical housing is the most desirable need in rural areas of developing countries. These regions often suffer significant loss of life during a seismic event. To enable an efficient and cost-effective solution, a new concept of construction, i.e. a wallette of interlocking blocks with movability at the interface and rope reinforcement, is investigated. The novel interlocking block is made of coconut fibre reinforced concrete (CFRC). The reason for using coconut fibre is their highest toughness amongst natural fibres. This paper describes the in-plane behaviour of the interlocking wallette under earthquake loadings. The wallette response is measured in terms of induced acceleration, block uplift, top maximum relative displacement and rope tension. The applied earthquake loadings cannot produce any damage in the structure, i.e. blocks and/or ropes. The response of the wallette is explained in detail along with correlation of materials aspect with structural behaviour.
\end{abstract}

KEYWORDS: Fibre reinforcement; Concrete; Composite; Acceleration; Mechanical properties

Citation/Citar como: Ali Majid (2016) Use of coconut fibre reinforced concrete and coconut-fibre ropes for seismicresistant construction. Mater. Construcc. 66 [321], e073. http://dx.doi.org/10.3989/mc.2016.01015.

RESUMEN: Uso de hormigón reforzado con fibras de coco para construcciones sismo resistentes. En las zonas rurales de los países en desarrollo, entre las características principales que deben reunir las viviendas es que sean tanto económicas como sismoresistentes, ya que en estas zonas la pérdida de vidas humanas debido a los terremotos es aun elevada. A fin de hallar una solución que cumple con estos requisitos de manera técnica y económicamente efectiva, se ha investigado un nuevo concepto constructivo: un murete de bloques conjugados con movilidad en el interfaz y reforzado con cuerda. Este novedoso bloque conjugable está realizado en hormigón reforzado con fibra de coco (CFRC), elegida por su alta tenacidad, la mayor de entre las fibras naturales. El artículo describe el comportamiento dentro del plano del murete conjugado frente a las cargas sísmicas. La respuesta de esta estructura se ha medido en función de la aceleración inducida, el levantamiento de los bloques, el desplazamiento relativo máximo y la tensión de las cuerdas, determinándose que ni los bloques ni las cuerdas han resultado dañados por las cargas sísmicas aplicadas. La respuesta del murete se describe en detalle, relacionando las propiedades de los materiales con su comportamiento estructural.

PALABRAS CLAVE: Refuerzo con fibras; Hormigón; Composite; Aceleración; Propiedades mecánicas

Copyright: (C) 2016 CSIC. This is an open-access article distributed under the terms of the Creative Commons Attribution-Non Commercial (by-nc) Spain 3.0 License. 


\section{INTRODUCTION}

\subsection{Background}

Earthquake has been one of the most hazardous threats that have caused collapse of houses and thus resulted in fatalities. The main reasons include the poor quality of the materials and inadequate overall strength of the structure because of old traditional construction techniques (1). These fatalities decreased a lot in the developed countries during the second half of $20^{\text {th }}$ century. This is due to the technology developed for building seismic-resistant houses. At the same time, it requires expensive materials like steel reinforcement that ultimately results in costly housing. These costly materials cannot be used in developing or underdeveloped countries at large scale especially in rural areas, because people simply cannot afford it. Other alternatives are still under investigation to build earthquake-resistant houses at low cost. One key aspect is to reduce the material cost considerably and another is to develop a construction technology to be adopted in seismic prone rural regions.

\subsection{New cost-saving and environmental-friendly construction material}

The price of reinforcing materials will automatically be cut down if the local resources are used. One option is to utilize natural fibres as concrete reinforcement. There is a wide range of natural fibres, namely sisal, bamboo, coir (coconut fibre), jute, and many others (2-4). Studies have shown that natural fibres are good alternatives at lower cost and promotes sustainable development as they are renewable and recyclable materials (5-8). Moreover, natural fibres are generally abundantly available in most developing countries where the need of proper and cheap housing construction is on high demand (9). In this study, coconut fibres are selected because of their highest toughness compared to that of other natural fibres. Strain values of $24 \%$ and $39 \%$ are reported for single and bundle coconut fibres, respectively, while the strain of other natural fibres are in the range of $3-6 \%(10,11)$.

Durability of natural fibres has remained a topic of interest for many researchers. In a study by (12), the effect of an acidic and alkaline environment on the curing of concrete was investigated for slabs (750 $\mathrm{mm}$ long, $500 \mathrm{~mm}$ wide and $40 \mathrm{~mm}$ thick). The considered parameters were two different grades of concrete (M20 and M30, showing different strengths of concrete i.e. 20 and $30 \mathrm{MPa}$, respectively), three contents of coir rope reinforcement $(0.95 \%, 1.43 \%$ and $1.91 \%)$ and rope pre-treatment (untreated and coated with epoxy resin). The mass loss and strength deterioration against $\mathrm{HCl}$ and
$\mathrm{Na}_{2} \mathrm{SO}_{4}$ attacks over 2 years were determined. The reduction in flexural strength was approximately $2 \%$ and $3-4 \%$ for acid and sulphate environments, respectively. It was concluded that the slabs were not affected by the acid or sulphate environment and the durability of the proposed coir rope reinforced bio-composite concrete panels was good. In another study by (8), the variation in chemical composition and tensile strength of four natural fibres, i.e. coconut, sisal, jute and hibiscus cannabinus fibres, was investigated when subjected to alternate wetting and drying, continuous immersion for 60 days in water, saturated lime and sodium hydroxide. The chemical composition of all the fibres changed because of immersion in the solutions described above. Continuous immersion was found to be critical due to the loss of their tensile strength. However, coconut fibres were reported as the best option for retaining a good percentage of their original tensile strength in all tests.

In most practical situations, raw natural fibres were not able to provide adequate interfacial bond strength. A considerable amount of work has been done to improve the fibre surfaces for increasing the bond strength with the surrounding matrix. The pretreatment can be achieved by physical and chemical modifications of the fibre surface. The main constituents of the surface of a coconut fibre are lignin and cellulose. Boiled and washed fibres are stiffer and tougher compared to raw fibres because they have higher lignin and cellulose contents due to the washout of extractives. The process could also remove a part of the extraneous fibre surface components which may resist the formation of the bond between fibres and cement paste. It was shown in (5) that compared to fibres without pre-treatment, the internal bond between washed/boiled fibres and the cement paste was doubled. Thus, washed and boiled fibres will effectively increase the fibre-matrix bond strength.

The combined use of sodium alginate and calcium chloride effectively improved the ultimate tensile strength of fibres by $18 \%$ (13). Sodium alginate is a weak acidic food gel while calcium chloride is almost neutral, both of them are safe to use and are environmentally friendly. John et al. (14) studied the coconut fibre reinforced blast-furnace slag cement mortar taken from the internal and external walls of a 12 year old house. The panel of the house was produced using 1:1.5:0.504 (binder: sand: water, by mass) mortar reinforced with $2 \%$ of coconut fibres by volume. The cement was fully carbonated after the considered duration. Fibres removed from the old samples were reported to be undamaged. No significant difference was found in the lignin content of the fibres removed from external and internal walls, confirming the durability of coconut fibres in cement composites. 


\subsection{Structural advantages of proposed construction}

Masonry buildings are not good in bearing lateral load resulting from strong ground motions. One remedial measure is to reinforce the brick construction using stiffeners composed of steel reinforced concrete grout or fibre reinforced polymer sheets. This could considerably improve the strength of the construction against earthquake loading $(1,15,16)$. However, the problem lies on economical aspect. The price of steel reinforced concrete is still quite expensive for most people particularly residing in rural areas. Thus, the practice of steel reinforced masonry is not adopted widely. An economical solution for earthquake-resistant housing can surely help in avoiding structure collapse at a large scale, ultimately resulting in saving many lives.

On the other hand, researchers have also suggested the use of interlocking blocks to replace the normal bricks and eliminate mortar from masonry construction. It can reduce the construction time significantly and thus cut the construction cost. Most of these blocks are hollow (17-19), some are solid (20) and curved (21), but in few cases, with provisions of holes for reinforcement. These blocks can be prepared mechanically or manually, but in some cases, it requires very complicated moulds and manual casting. Usually, the material is concrete (17-19); stabilized soil $(21,22)$ and sand-fly ash $(20,23)$ are also used for few blocks. The thickness of these blocks also varies, making them suitable either for load bearing, partition or cladding walls. Interlocking mechanism is provided either by horizontal, vertical or both interconnecting keys for in-plane and out-of-plane directions. It may be noted that the interlocking keys of hollow blocks alone are normally not sufficient to resist stresses of design load for an assembled wall in a structure due to elimination of mortar layers (24). This might be because of limited key projection. To overcome this problem, normal reinforced concrete is used at regular intervals in the holes provided in hollow blocks. This makes the structure a little bit expensive. In some cases, relatively lesser mortar (as compared to that required in normal brick masonry) is used with the interlocking blocks (22).

It is anticipated that the mortar-free construction can also help in energy dissipation during a seismic event. Coconut fibre reinforced concrete (CFRC) members with cracks have more damping than those without cracks (25). To further enhance the damping capability of the structure, CFRC interlocking blocks are used in the mortar-free construction. Interlocking block has a unique shape in such a way that they could be stacked together by aligning the interlocking "key" together. This current study is conducted to understand the seismic behaviour of mortar-free structure having newly developed interlocking CFRC blocks and rope reinforcement.
The reason of using rope is to keep wall integrity and to allow movement of interlocking blocks because of rope elongation during strong ground motions.

\section{EXPERIMENTAL WORK}

To understand the seismic behaviour of mortar free interlocking CFRC block wall, shake table investigations have been performed. The details of the interlocking block, preparation of CFRC, material properties determination and wallette testing are explained below.

\subsection{Innovative interlocking block}

A novel interlocking block is especially designed for resisting earthquake loading in a mortar-free construction. The shape of the block is shown in Figure 1. The block has overall dimensions of $400 \mathrm{~mm}$ long $\times 200 \mathrm{~mm}$ wide $\times 195 \mathrm{~mm}$ high with in-plane and out-of-plane interlocking keys of $45 \mathrm{~mm}$ height. The blocks are made using specially made wooden moulds. Wood is selected because of its economy and frequent availability in rural areas compared to metal like steel. The mass of block is $24 \mathrm{~kg}$, and thus workers can handle it because of mortar-free construction. The blocks can move relatively to each other when inertial forces are activated during earthquake. This movement can then lead to energy dissipation. The blocks will settle back to its original position because of inclined key. The maximum uplift should be restricted up to the key height which is ensured by the presence of ropes. Two holes are provided in the block for rope reinforcement. The block is prepared with coconut fibre reinforced concrete (CFRC). CFRC is made with $5 \mathrm{~cm}$ long fibres having a content of $1 \%$ by mass of concrete material. The mix design ratio (cement: sand: aggregates) is $1: 4: 2$ with a water-cement ratio of 0.75 . It is important to note that the content of sand is kept more as compared to that of aggregates so that more mortar in concrete is available for grabbing $1 \%$ fibre content. The consequential composite will facilitate to have a smooth finish-surface of the block.

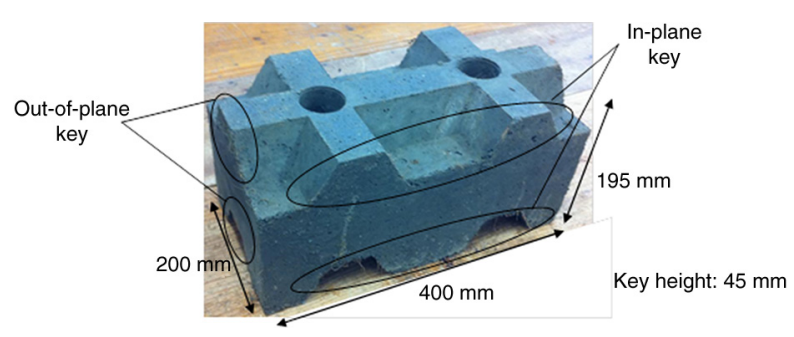

FIGURE 1. CFRC interlocking block with overall dimensions. 


\subsection{CFRC blocks and test preparation}

Ordinary Portland cement, sand, aggregates, water and imported brown coconut fibres were used for preparation of CFRC. The maximum size of aggregates was $12 \mathrm{~mm}$ (passing through $12 \mathrm{~mm}$ sieve and retained at $10 \mathrm{~mm}$ sieve). The mean diameter of coconut fibres is $0.25 \mathrm{~mm}$. A pan type concrete mixer was used in preparing CFRC. A layer of coconut fibres (approximately one-fourth of $1 \%$ ) was spread in the pan, followed by spreading of aggregates, sand and cement. The first layer of fibres was hidden under the dry concrete materials with the help of a spade. Then, another layer of coconut fibres followed by layers of aggregates, sand and cement was spread. This process was repeated until the rest of materials were put into the mixer pan. Water was then added, and the mixer was rotated for five minutes. A slump test was always performed before pouring it into moulds. The slumps for CFRCs were 10 to $20 \mathrm{~mm}$, but CFRC was workable in spite of this low slump.

Special wooden mould was prepared in such a way that the block was cast inverted. Mould was filled in four layers, i.e. approximately up to (i) $75 \mathrm{~mm}$, (ii) $150 \mathrm{~mm}$, (iii) $175 \mathrm{~mm}$ and (iv) $195 \mathrm{~mm}$. Each layer was compacted first by rodding with $16 \mathrm{~mm}$ diameter rod and then the moulds were lifted up to a height of approximately $200-300 \mathrm{~mm}$ and dropped to the floor for self-compaction of the fibre concrete and to remove air voids from CFRC. Cylinders $100 \mathrm{~mm}$ in diameter and $200 \mathrm{~mm}$ in height and beam-lets $100 \mathrm{~mm}$ wide, $100 \mathrm{~mm}$ deep and $500 \mathrm{~mm}$ long were also prepared using standard procedures for determining the mechanical properties. Four interlocking blocks, six cylinders and three beam-lets were prepared from one batch of CFRC. Footing of $1500 \mathrm{~mm}$ long, $600 \mathrm{~mm}$ wide and $200 \mathrm{~mm}$ deep was also prepared with CFRC but with a less fibre content $(0.25 \%)$ because of presence of steel reinforcement. The reason for using CFRC in foundation was to observe damages (if any) because of friction between blocks and foundation. Steel reinforcement was used so that the foundation can be easily shifted on and off to the shake table, otherwise steel reinforcement is not required. Holes were provided in the foundation for insertion of rope reinforcement. A groove $(1200 \mathrm{~mm}$ long, $200 \mathrm{~mm}$ wide and $75 \mathrm{~mm}$ deep) was also provided in the foundation for holding the interlocking blocks. All specimens were cured for 28 days, then dried for 48 hours and finally white washed before testing to enable a clear identification of cracks.

\subsection{Testing procedure}

\subsubsection{Cylinder, beam-let, rope and block tests}

All cylinders were tested in a compression testing machine to determine mechanical properties, i.e. modulus of elasticity $\mathrm{E}$, compressive strength $\sigma$, corresponding strain $\varepsilon$, and splitting tensile strength STS using the standard procedures NZS 3112: Part 2 (26). Each cylinder was capped with plaster of Paris for uniform distribution of load before testing of the $\mathrm{E}$ and $\sigma$. One additional parameter, compressive toughness, $T_{c}$, was also calculated from this testing. The procedure to find $T_{c}$ is taken from Libre et al. (27). All beam-lets were tested using the standard procedures NZS 3112: Part 2 (26) in a universal testing machine of capacity $100 \mathrm{kN}$ using four-point loads to obtain modulus of rupture MOR and corresponding deflection $\Delta$. Two additional parameters, flexural toughness $\mathrm{T}_{\mathrm{f}}$ and cracking load $\mathrm{P}_{\text {Crack }}$ were also found from the same testing. Cracking load is the load taken by fibres and part of concrete after the first visible crack is produced (25). The concept of finding flexural toughness is taken from Richardson et al. (28). Coconut fibre rope is tested in Avery machine to determine its tensile strength and modulus of elasticity (29). CFRC interlocking blocks were also tested in compression testing machine for their compressive strength, elastic modulus, compressive toughness and Poisson's ratio (30). An average of three readings were taken for every property.

\subsubsection{Wallette instrumentation and loading selection/sequence}

The experimental set up for wallette (having size $1.2 \mathrm{~m}$ wide and $1.68 \mathrm{~m}$ high) on shake table along with details of attached equipment for measuring its response is shown in Figure 2. The wallette size is restricted and no mass is put at the top of wallette because of shake table load capacity. The mass of structure (foundation and wallette) is 1.4 tonne. Even though it was unrealistic to perform tests without a top mass, the sole purpose of wallette testing was to have an approximate idea of the damping in mortar-free shear wall structures. The results will be different with a seismic top mass. The testing of wallette with a top mass or even with a diaphragm is intended in the near future using a larger shake table. Coconut fibre ropes of $36 \mathrm{~mm}$ diameter are used as vertical reinforcement. A post-tension force of $200 \mathrm{~N}$ was applied manually in the un-grouted ropes. The ropes are anchored at the foundation and top of wallette with the help of specially made assembly as shown in enlarged views in Figure 2. The shown rope is in post-tensioned position. Assembly consists of two iron angles, each welded with steel plate having holes for screwing with bolts (as shown in enlarged view at wallette top for left rope). For recording rope tension, an additional assembly was made i.e. two load cells of $10 \mathrm{kN}$ each were attached to a steel plate (as shown in enlarged view at wallette top for right rope). This whole assembly is taken as one load cell for measuring rope tension of one rope. 


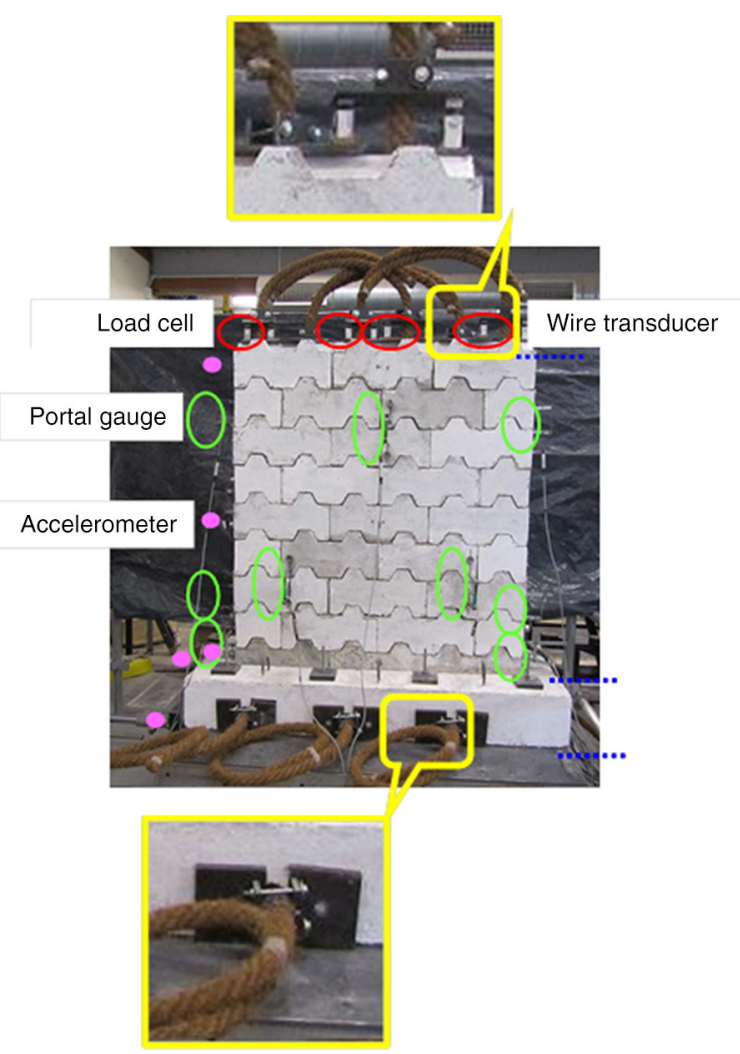

FIGURE 2. Wallette on shake table with instrumentation.

The wallette is instrumented with the following:

(i) five accelerometers along wallette height for determining the induced acceleration (at shake table, at foundation, at the lowest block, at mid-height and at top of the wallette).

(ii) four load cells for measuring rope tensioning during earthquake loading (two at outer ropes and two at middle ropes on wallette top).

(iii) nine portal gauges for quantifying block relative movement (three on left and on right sides, respectively, and three on wallette face along the wallette height).

(iv) a wire transducer at the top to measure the relative wallette top displacement. Two more transducers, one on shake table and one on foundation, are also attached.

The characteristics of selected earthquakes are presented in Table 1. The magnitude of these earthquakes varies from 7 to 8.8. The fault mechanism is either strike-slip, subduction or reverse. The size of shake table is $1.5 \mathrm{~m} \times 1.0 \mathrm{~m}$ and it has uni-axial facility. The shake table has a limitation of applying a lateral displacement of $\pm 110 \mathrm{~mm}$. Therefore the selected earthquakes are scaled down accordingly. Table 2 shows the scaling and applied sequence of earthquake loadings. The displacement-time histories of shake table, without and with structure, confirm that the table is capable of simulating ground motions with accuracy. Since the primary objective is to observe the behaviour of mortar-free wallette under the seismic loading, the ground motions are applied in increments of $20 \%$. The response of wallette under Kobe 1995 earthquake is explained in detailed, while its response under different earthquake loadings of Table 2 are also compared in order to understand the behaviour of mortar-free wallette made of innovative CFRC interlocking blocks reinforced with coconut-fibre rope. Since no damage was observed under any earthquake loading for the selected wallete, only one specimen was used for the current testing programme.

\section{DISCUSSION OF RESULTS}

\subsection{Material properties}

The properties of CFRC samples (cylinders and beam-lets) are presented in Table 3. Mechanical properties of CFRC are analysed from experimental data using the standard procedures (26). Modulus of elasticity, $E$, is calculated as the ratio of stress

TABLE 1. Characteristics of earthquake loadings

\begin{tabular}{lccllcc}
\hline & \multicolumn{7}{c}{ Characteristics } \\
\cline { 2 - 7 } Earthquake & $\begin{array}{c}\text { Magnitude } \\
(\mathbf{M w})\end{array}$ & $\begin{array}{c}\text { Depth } \\
\mathbf{( k m )}\end{array}$ & Distance (km) & $\begin{array}{c}\text { Fault } \\
\text { Mechanism }\end{array}$ & $\begin{array}{c}\text { Station's } \\
\text { soil }\end{array}$ & $\begin{array}{c}\text { Near-fault } \\
\text { effect }\end{array}$ \\
\hline El Centro, USA 1940 & 7 & 10 & 6 & Strike slip & Deep broad & No \\
Hokkaido, Japan 2003 & 8.3 & 33 & 46 & Subduction & - & No \\
Llolleo, Chile, 1985 & 7.8 & 33 & 23 & Subduction & Rock & No \\
Tabas, Iran 1978 & 7.4 & 5 & 2 & Reverse & Rock & Yes \\
Santiago, Chile 2010 & 8.8 & 35 & Epicenter $=35.909^{\circ} \mathrm{S}$ & Subduction & - & No \\
& & & $72.733^{\circ} \mathrm{W}$ & & & Yes \\
Kobe, Japan 1995 & 7.2 & 17.9 & 20 & Strike slip & - & Yes \\
Duzce, Turkey 1999 & 7.2 & 10 & 0 & Strike slip & Deep broad & Yes \\
Kashmir, Pakistan 2005 & 7.6 & 10 & 45 & Subduction & - & Yes \\
\hline
\end{tabular}


TABLE 2. Scaling and applied sequence of earthquake loadings

\begin{tabular}{|c|c|c|c|c|c|c|}
\hline \multirow[b]{2}{*}{ Earthquake } & \multicolumn{2}{|r|}{ Original } & \multirow[b]{2}{*}{$\begin{array}{l}\text { Scaling } \\
\text { factor }\end{array}$} & \multicolumn{2}{|r|}{ Scaled } & \multirow[b]{2}{*}{$\begin{array}{l}\text { Loading } \\
\text { sequence* }\end{array}$} \\
\hline & PGA (g) & $\begin{array}{c}\text { Maximum } \\
\text { displacement }(\mathrm{mm})\end{array}$ & & PGA (g) & $\begin{array}{c}\text { Maximum } \\
\text { displacement }(\mathrm{mm})\end{array}$ & \\
\hline El Centro, USA 1940 & 0.35 & 80 & 1 & 0.35 & 80 & $1 \mathrm{a}, 1 \mathrm{~b}, 1 \mathrm{c}, 1 \mathrm{~d}, 1 \mathrm{e}$ \\
\hline Hokkaido, Japan 2003 & 0.28 & 270 & 0.3 & 0.09 & 81 & $2 \mathrm{a}, 2 \mathrm{~b}, 2 \mathrm{c}, 2 \mathrm{~d}, 2 \mathrm{e}$ \\
\hline Llolleo, Chile, 1985 & 0.65 & 113 & 0.9 & 0.59 & 102 & $3 \mathrm{a}, 3 \mathrm{~b}, 3 \mathrm{c}, 3 \mathrm{~d}, 3 \mathrm{e}$ \\
\hline Tabas, Iran 1978 & 1.04 & 190 & 0.5 & 0.52 & 95 & $4 \mathrm{a}, 4 \mathrm{~b}, 4 \mathrm{c}, 4 \mathrm{~d}, 4 \mathrm{e}$ \\
\hline Santiago, Chile 2010 & 0.65 & 93 & 1 & 0.65 & 93 & $5 \mathrm{a}, 5 \mathrm{~b}, 5 \mathrm{c}, 5 \mathrm{~d}, 5 \mathrm{e}$ \\
\hline Kobe, Japan 1995 & 0.84 & 178 & 0.6 & 0.50 & 107 & $6 \mathrm{a}, 6 \mathrm{~b}, 6 \mathrm{c}, 6 \mathrm{~d}, 6 \mathrm{e}$ \\
\hline Duzce, Turkey 1999 & 0.54 & 485 & 0.2 & 0.11 & 97 & $7 \mathrm{a}, 7 \mathrm{~b}, 7 \mathrm{c}, 7 \mathrm{~d}, 7 \mathrm{e}$ \\
\hline Kashmir, Pakistan 2005 & 0.24 & 110 & 1 & 0.24 & 110 & $8 \mathrm{a}, 8 \mathrm{~b}, 8 \mathrm{c}, 8 \mathrm{~d}, 8 \mathrm{e}$ \\
\hline
\end{tabular}

Note: $*$ a b, c, d and e in loading sequence corresponds to $20 \%, 40 \%, 60 \%, 80 \%$ and $100 \%$, respectively, of scaled earthquake loadings. Applied sequence was from a to e for each earthquake loading.

TABLE 3. CFRC properties

\begin{tabular}{|c|c|c|c|c|c|c|c|c|c|c|c|}
\hline \multirow[b]{2}{*}{ Structural member } & \multicolumn{5}{|c|}{ Cylinder testing } & \multicolumn{5}{|c|}{ Beam-let testing } & \multirow[b]{2}{*}{$\begin{array}{l}\text { Density } \\
\left(\mathrm{kg} / \mathrm{m}^{3}\right)\end{array}$} \\
\hline & $\begin{array}{c}\sigma \\
(\mathbf{M P a}) \\
\end{array}$ & $\varepsilon(\%)$ & $\begin{array}{c}E \\
(\mathrm{GPa}) \\
\end{array}$ & $\begin{array}{c}\mathbf{T}_{\mathrm{c}} \\
(\mathbf{M P a})\end{array}$ & $\begin{array}{c}\begin{array}{c}\text { STS } \\
(\mathrm{MPa})\end{array} \\
\end{array}$ & $\begin{array}{l}\text { MOR } \\
\text { (MPa) }\end{array}$ & $\begin{array}{c}\Delta \\
(\mathbf{m m})\end{array}$ & $\begin{array}{c}\mathbf{P}_{\text {crack }} \\
\mathbf{k N}\end{array}$ & $\begin{array}{c}\Delta_{\max } \\
(\mathrm{mm})\end{array}$ & $\begin{array}{c}\text { TTI } \\
(-)\end{array}$ & \\
\hline Blocks (30) & 20.7 & 0.24 & 19.3 & 0.25 & 2.75 & 3.6 & 1.21 & 3.3 & 11.8 & 4.51 & 2128 \\
\hline Foundation & 20.9 & 0.21 & 19.6 & 0.20 & 2.85 & 3.2 & 1.07 & 2.4 & 8.2 & 4.12 & 2203 \\
\hline
\end{tabular}

change to strain change in the elastic range. Stressstrain relationship for each specimen is the average of readings taken by two LVDTs attached to the specimens. The maximum stress value of stressstrain curves is taken as compressive strength $\sigma$ and its corresponding strain $\varepsilon$ is also noted. Compressive toughness, $T_{c}$, is calculated as the total area under the stress-strain curve (27). Other researchers have taken it as area after the maximum stress up to $1 \%$ strain (31). No spalling of fibre-concrete from the cylinder is observed in $\mathrm{E}$ and $\sigma$ test. The maximum load from load-time curve of STS test is taken for the calculation of STS. CFRC cylinders stayed together after cracks and even when the test was continued up to more than $800 \mathrm{~s}$, the two pieces were not separated. The maximum load from the load-displacement curve of flexure test is taken for the calculation of modulus of rupture, MOR. CFRC beam-lets were held together even after the maximum load (i.e. the load at first crack). CFRC beams were intentionally broken in to two halves to observe fibre failure. Two types of fibre failure were observed: (i) fibre breaking and (ii) fibre pull-out. Flexural toughness is measured as the total toughness index (TTI). It is the ratio of area under load-displacement curve up to the maximum deflection to the area under curve up to first-crack load. Usually, toughness index is taken as the area under the curve up to $3,5.5$ or 10.5 times the first-crack deflection to area under curve at first-crack deflection, and they are designated as $\mathrm{I}_{5}, \mathrm{I}_{10}$ and $\mathrm{I}_{15}$, respectively, (28). CFRC has relatively less density as compared to that of plain concrete, because of presence of low density fibres in concrete. A smaller density is significant since less inertia forces will be activated in earthquakes and thus smaller structural dimension is required to withstand the reduced earthquake impact. CFRC (used for blocks) has $\sigma, \mathrm{E}$ and MOR of $20.7 \mathrm{MPa}$, 19.3 $\mathrm{GPa}$ and 3.6 MPa, respectively.

The properties of rope are presented in Table 4. The initial cross-section dimension of rope is taken in calculation of its stress. Rope of $36 \mathrm{~mm}$ diameter is having a tensile strength and ultimate elongation of $15.3 \mathrm{MPa}$ and $190 \%$, respectively, (29). It is important to note that the rope undergoes an elongation of $163 \%$ at peak load (first rupture). This is the property of coconut-fibre rope that it can undergo such a high elongation. The typical stressstrain curve of a $36 \mathrm{~mm}$ diameter coconut-fibre rope is shown in Figure 3 (29). The maximum load (i.e. corresponding to point ' $\mathrm{C}$ ' in Figure 3) is taken for the calculation of tensile strength of the rope and its corresponding strain is noted. The elongation up to peak load (i.e. up to point $\mathrm{C}$ ) and total elongation (i.e. up to point K) are measured. It can be observed

TABLE 4. Rope properties (29)

\begin{tabular}{cccc}
\hline $\begin{array}{c}\text { Tensile strength } \\
\text { (MPa) }\end{array}$ & $\begin{array}{c}\text { Corresponding } \\
\text { strain (\%) }\end{array}$ & $\begin{array}{c}\text { Elongation at } \\
\text { peak load (\%) }\end{array}$ & $\begin{array}{c}\text { Ultimate } \\
\text { elongation (\%) }\end{array}$ \\
\hline 15.3 & 0.63 & 163 & 190 \\
\hline
\end{tabular}




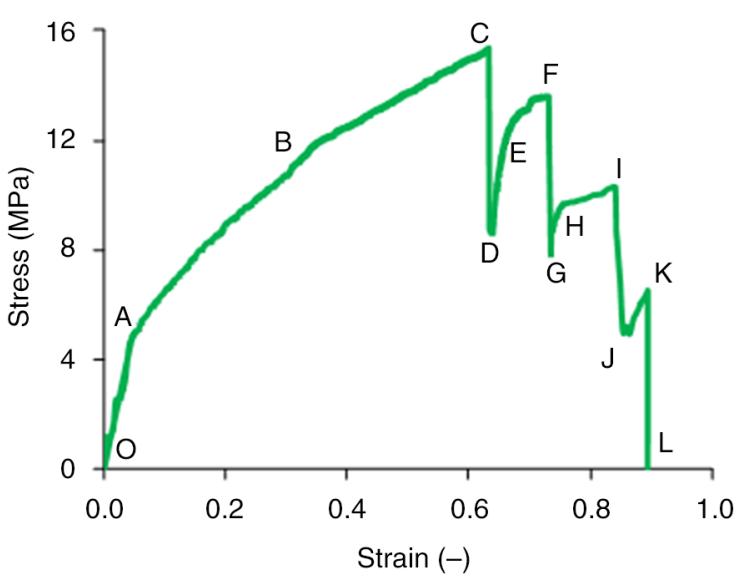

FIGURE 3. Typical stress-strain curve of a $36 \mathrm{~mm}$ diameter coconut fibre rope (29).

from the figure that the stress-strain curve has three approximately linear segments $(\mathrm{OA}, \mathrm{AB}, \mathrm{BC})$ before the maximum load is achieved. It means that the stress-strain relation is non-linear before the peak stress, but the curve OC can be separated into three regions of constant slope. The transition between these slopes is not a definite point but, in fact, an arc. The nonlinear nature of the stress-strain curve is due to the development of plastic strain. Since the rope of a particular diameter is made of small diameter curled-ropes, it can be observed on curve CL that the successive ruptures occurred. When the rope was put under tensile load, the stresses in the curled-ropes were not the same. Initially, one curled rope (out of four) with the maximum stress ruptured (at point $\mathrm{C}$ in Figure 3) and the stress suddenly dropped to point $\mathrm{D}$. The remaining curled ropes took the tension load and the stress started increasing from point $\mathrm{D}$ to $\mathrm{E}$ and then from $\mathrm{E}$ to $\mathrm{F}$, showing two slopes $\mathrm{DE}$ and EF having a smooth arc between them. At point F, second curled ropes ruptured and the stress again dropped suddenly to point $\mathrm{G}$. The rope tensile test continued in similar manner, breaking the remaining curled ropes and having two slopes GH and HI for the third curled-rope and one slope JK for the last curled-rope. The stress-strain relationship after the peak load depends on the number of curled ropes present in a particular diameter rope. The details of rope testing are explained in (29).

The properties of CFRC interlocking block are presented in Table 5. Interlocking blocks have a compressive strength, elastic modulus, compressive toughness and Poisson's ratio of $16.5 \mathrm{MPa}$,
2.34 GPa, 0.56 MPa and 0.015, respectively, (30). Load-deformation curves were recorded during the test of interlocking block, which are then converted to average stress-strain curves for determining block properties. For a single standard block test, the maximum load was $370 \mathrm{kN}$ and the corresponding deformation was $2.28 \mathrm{~mm}$. It was observed that cracks were initiated at the bottom interlocking keys of the block, with the first crack appearing in one of the corner interlocking keys on the bottom side of the standard block before the ultimate load was reached, at approximately $90 \%$ of its peak load, propagating upwards. The reason could be a smaller bearing area of the bottom interlocking keys in comparison to the upper keys, especially at the corners. The appearance of the first crack was always in one of the corners interlocking at the bottom side of the block, but not in the respective key of the other samples. Its reason could be the uneven compaction in the bottom interlocking keys as the blocks were prepared manually. More cracks appeared in the other interlocking keys on the bottom side as the load approached its maximum value. When the load decreased after reaching its peak value, the cracks continued to propagate upwards and widen. The cracks were bridged by the fibres, and the parts of the block were in contact with each other at the end of the test. Average stress-strain curve of a standard CFRC interlocking block (Figure 4, (30)) is analysed in a similar manner to that of CFRC cylinders. It is important to note that the block has different top and bottom contact areas, resulting in different top and bottom stresses. There is no guideline available for which stress is to be taken to represent the compressive strength of the interlocking blocks and to calculate other engineering properties (modulus of elasticity and compressive toughness). These bottom and top contact areas are used to calculate the bottom and top stresses, respectively, and then their average is taken to represent the compressive strength of the block. The axial strains at the four corners are slightly different. An average of the top and bottom stresses, and four vertical (or axial) strains are taken as the average-stress and average-strain, respectively. The details of block testing are explained in (30).

It may be noted that the compressive strength, corresponding vertical strain, elastic modulus and compressive toughness of CFRC cylinders are $20.7 \mathrm{MPa}$, $0.24,19.4 \mathrm{GPa}$ and $0.25 \mathrm{MPa}$, respectively, whereas those of CFRC blocks are 16.5 MPa, 1.3, 2.34 GPa and $0.56 \mathrm{MPa}$, respectively. There is a huge difference in strain, elastic modulus and compressive strain of

TABLE 5. CFRC interlocking block properties (30)

\begin{tabular}{|c|c|c|c|c|c|}
\hline \multirow{2}{*}{$\begin{array}{l}\text { Compressive } \\
\text { strength (MPa) }\end{array}$} & \multicolumn{2}{|c|}{ Corresponding strain $(\%)$} & \multirow{2}{*}{$\begin{array}{l}\text { Poisson's } \\
\text { ratio (-) }\end{array}$} & \multirow{2}{*}{$\begin{array}{c}\text { Elastic } \\
\text { modulus (GPa) }\end{array}$} & \multirow{2}{*}{$\begin{array}{c}\text { Compressive } \\
\text { toughness (MPa) }\end{array}$} \\
\hline & vertical & horizontal & & & \\
\hline 16.5 & 1.3 & 0.02 & 0.015 & 2.34 & 0.56 \\
\hline
\end{tabular}




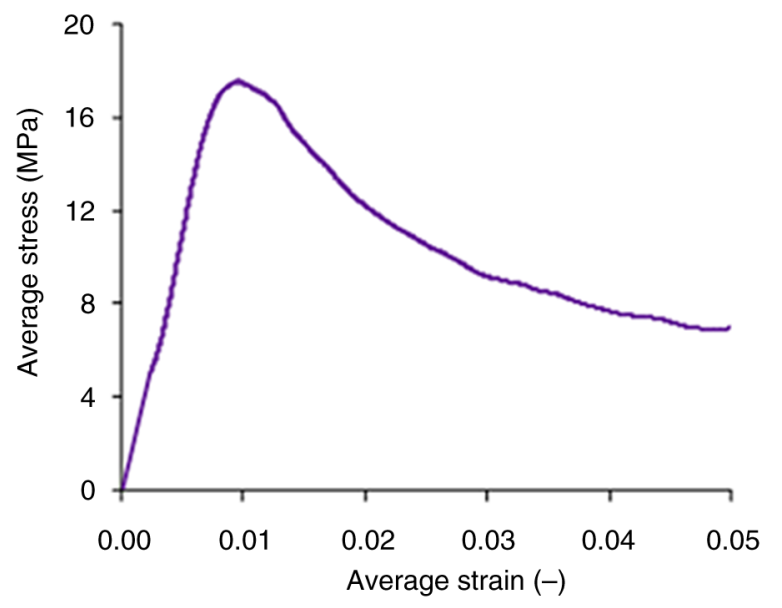

FIGURE 4. Typical average stress-strain of a standard CFRC interlocking block (30).

CFRC cylinders and CFRC interlocking blocks. This can be attributed to the novel shape of the interlocking block. In particular, difference of elastic modulus of $19.4 \mathrm{GPa}$ for CFRC cylinders and that of $2.34 \mathrm{GPa}$ for CFRC blocks is of much interest. As stated earlier, cracking was started in lower keys of interlocking block with much deformation resulting in higher strain compared to less deformation with small strain in CFRC cylinders. This led to lower E of earlier specimen compared to that of later specimen.

\subsection{Wallette response}

\subsubsection{Induced acceleration}

Induced vibrations are recorded using accelerometers attached along the height of the wallette. The accelerations recorded at foundation, bottom block, wallet mid-height and top under 100\% Kobe 1995 earthquake loading is shown in Figure 5a. The acceleration induced from foundation to bottom block is approximately the same due to rigid body motions as it can be observed in the enlarged rectangular and oval areas in same figure. However, the acceleration at wallette's mid-height and top is different as compared to that at foundation (oval-shaped enlarged view). Top acceleration has a decay trend from 3.8 to 4.0 seconds. It can be seen throughout the history that the response acceleration is more than the ground acceleration. Since the wallette aspect ratio (height to width) was around 1, it was difficult to perform free vibration and cyclic tests on wallette. However, it was done (in a separate study) on interlocking column so as to examine the viscous damping in the system and force-displacement capacity curves. Based on observed uplifts, it was presumed that there would also be damping in case of wallette because of mortar-free construction.

It may be noted that it is a common practice of researchers to use $5 \%$ critical damping for response
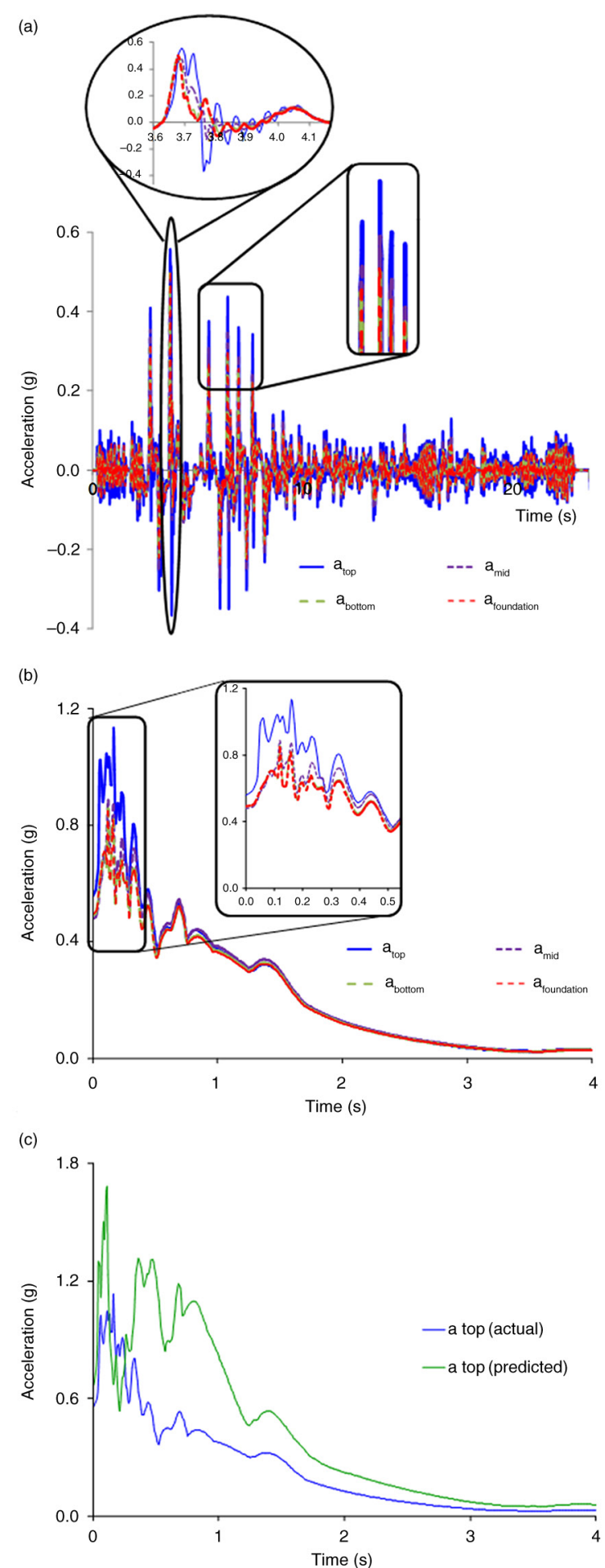

FIGURE 5. Induced acceleration under 100\% Kobe 1995 loading,

(a) Recorded acceleration-time history at foundation, bottom, mid and top of wallette, (b) Response spectrum for considered levels, and (c) Predicted vs actual response spectrum at wallette top.

spectra. However, a higher value of critical damping might be suitable/acceptable for mortar-free interlocking CFRC block structure. But it needs 
verification from any experimental or analytical testing which is out of scope of current work. That is why, for comparison purpose within the response of mortar-free construction, critical damping of 5\% is used in this study. The response spectrum represents the peak response of different single degree of freedom systems subjected to the acceleration history. Therefore, the response spectra corresponding to $5 \%$ critical damping for the considered levels are shown in Figure 5b. This was examined to check how structural components (attached to different heights of the wallette) will respond during strong ground motions? This can give an idea how efficient the proposed system is? At first, it was expected that the induced acceleration would reduce, but it did not happen because of tight interlocking of blocks. The predicted and actual response of structure (corresponding to $5 \%$ critical damping) under $100 \%$ earthquake loading is shown in Figure 5c. The predicted linear response is obtained by multiplying the $20 \%$ response by 5 . The $20 \%$ response is the response spectrum obtained from acceleration-time history recorded at the top of wallette under the $20 \%$ earthquake loading. Since the $20 \%$ loading compared to $100 \%$ loading is very small, it is assumed that it has given somewhat linear response. Therefore, this is multiplied by 5 to get the predicted linear response spectrum under $100 \%$ earthquake loading. Comparing the actual response to the predicted one, it can be noticed that the actual response is far less than the predicted one. It may be due to the reason that the structure is not perfectly rigid.

Figure 6 presents the peak response acceleration (PRA) at wallette top vs peak ground acceleration (PGA) for all considered earthquake loadings. PRA and PGA are shown in full and dotted lines, respectively. It can be easily seen that the PRA is more than PGA for all cases. The possible reason for this can be the mortar-free tight interlocking of the blocks and/or the free top end of wallette. It may also be noted that the PRA is not linear with respect to applied incremental PGA. The reason for this could be the non-linear activation of inertial force within the wallette due to applied ground motions.

\subsubsection{Block uplift}

The mortar-free wallette allows the block vertical relative movement at the interface during the applied earthquake loadings. The selected block uplifts (along the wallette height and also at bottom extreme ends) recorded during 100\% Kobe 1995 loading is shown in Figure 7. Even though the magnitude of uplift is quite small, i.e. only less than $3 \mathrm{~mm}$, but it has given some information, i.e. (i) the tested wallette is not perfectly rigid, (ii) there is tight interlocking of blocks, and (iii) there will be more movement in full-scale wall having top mass. Among the noted uplifts along the wallette height, the maximum uplift is at the left-bottom end, i.e. between first and second layer (shown in red in enlarged view), followed by the uplift between second and third layer (shown in purple), then the uplift between fifth and sixth layer (shown in green) and finally the uplift between seventh and eighth layer (shown in brown). It means the uplifts decrease along the height of wallette. It is also important to mention that the uplift occur in first three layers because of jerk during earthquake whereas the uplifts in upper layers happen when the blocks are coming to the original position. This can be claimed because of a bit delay in the uplift-time curves recorded along the wallette height. The uplift at right-bottom end is shown in dotted blue in the enlarged view. Its magnitude is little bit less than that at left bottom end. This might be caused because of an action similar to rocking (i.e. decay in movement).

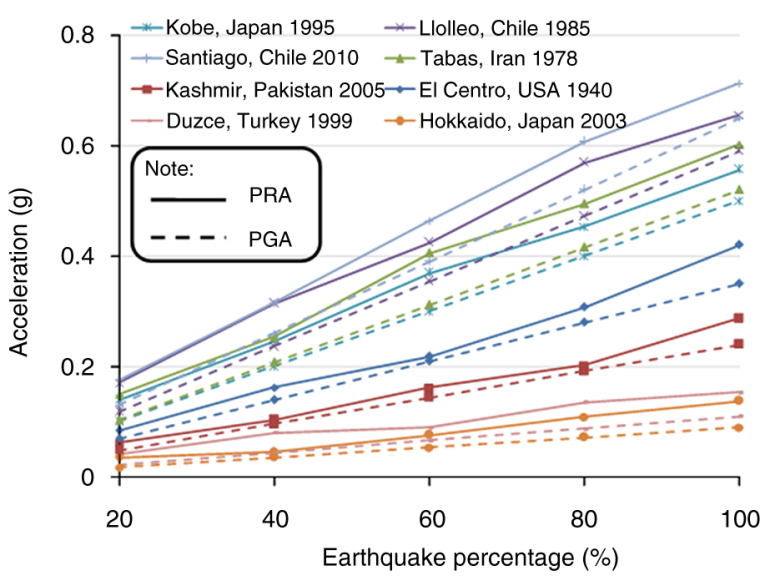

Figure 6. Peak Response Acceleration (PRA) at wallette top vs Peak Ground Acceleration (PGA) for considered earthquake loadings.

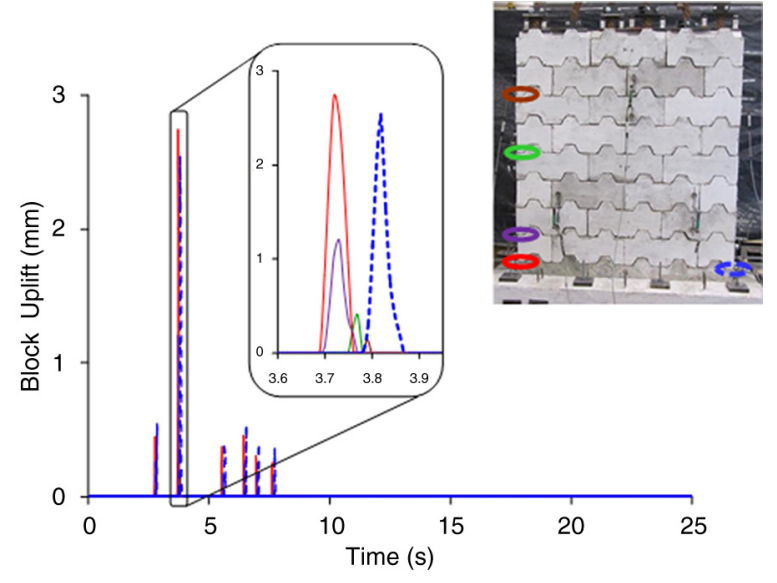

FIGURE 7. Selected block uplifts recorded during 100\% Kobe 1995 loading (Note: Solid lines shows recorded uplifts along wallette height at left side, whereas dash line shows uplift at bottom-right side). 
(a)

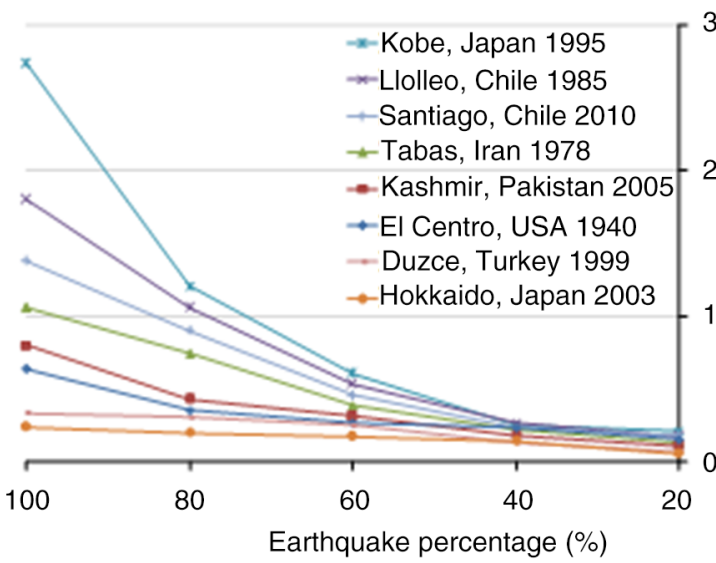

(b)

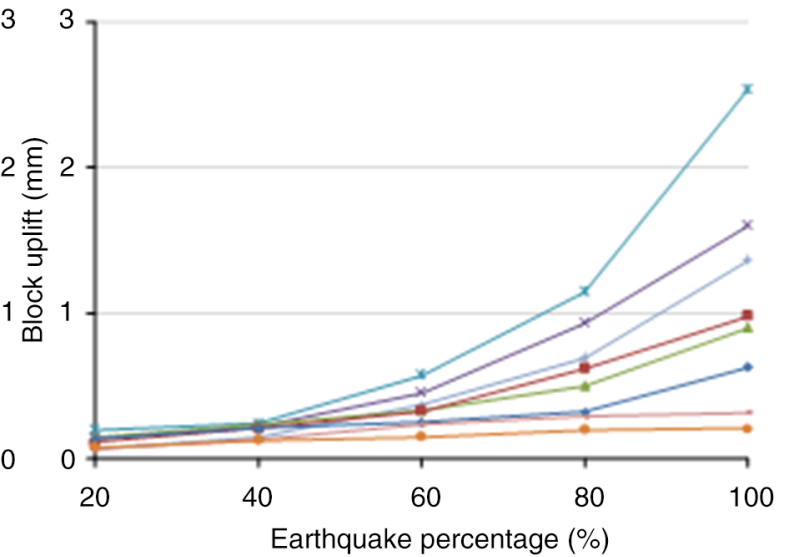

FIGURE 8. Maximum block uplifts for considered earthquake loadings; (a) bottom-left side and (b) bottom-right side [Locations are also shown in red and blue circles in Figure 7].

Since the maximum uplift is observed between first and second layers at the extreme sides, the uplifts at the bottom-left and bottom-right for all the considered earthquake loadings are shown in Figure $8 \mathrm{a}$ and $8 \mathrm{~b}$, respectively. The maximum uplift is caused due to Kobe 1995 loading, followed by Llolleo 1985, Santiago 2010, Tabas 1978, Kashmir 2005, El Centro 1940, Duzce 1999 and Hokkaido 2003. It may be noted that Santiago 2010 having PRA of $0.71 \mathrm{~g}$ cannot cause maximum uplift while Kobe has PRA of $0.56 \mathrm{~g}$. This might be because of combined earthquake characteristics like ground displacement, frequency and PGA. The uplifts at the left side are more than that at right side for all loadings except the Kashmir one. This is just due to the jerk produced because of the reverse movement (i.e., the uplift at left side will be observed when the shake table suddenly starts moving towards left side and vice versa). Similar to the trend of PRA, the block uplift is non-linear for the applied incremental earthquake loadings. The cause is same, i.e. the non-linear activation of inertial force.

It is important to mention that no visible cracks were observed because of many dynamic impacts of one block on other due to multiple block uplifts (maximum uplift only being $2.8 \mathrm{~mm}$ ) during the tests. For a full-scale structure, cracking in blocks might occur due to higher uplifts causing large dynamic impacts. Fibres can avoid micro-cracking up to some extent. If cracks occur, there would not be any spalling of concrete because of toughness (i.e. $0.56 \mathrm{MPa}$ ) and higher strain $(1.3 \%)$ of CFRC block. The standard blocks had their integrity with fewer cracks at the end of multiple block compression tests as explained in (30). This can help in ensuring the integrity of mortar-free walls during earthquake loadings. Otherwise, spalling of concrete can lead to early collapse of such walls.

\subsubsection{Maximum top horizontal relative displacement}

The cumulative of block uplifts along the wallette height has caused the relative displacement. The top relative-displacement is taken as the difference between the readings of linear variable differential transducers (LVDTs) attached at wallette top and foundation. The displacement means the in-plane horizontal displacement. The maximum values for all considered earthquake loadings are noted and presented in Figure 9. As expected, the response, in terms of maximum top relative-displacement, has increasing trend with the applied incremental loading, but this is not perfectly linear. This might be because of (i) mortar-free construction and (ii) activation of different inertial forces under the given ground motions. The tendency of earthquake loadings causing maximum relative-displacement is same as that for uplifts.

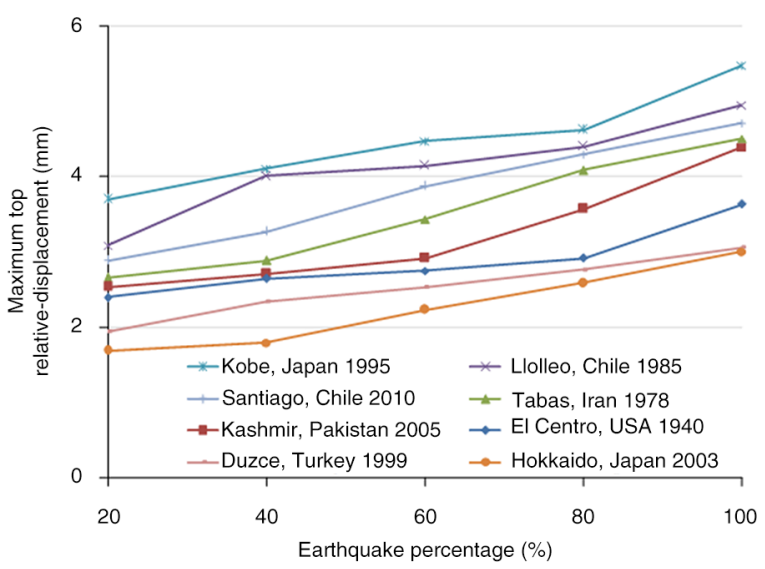

FIGURE 9. Maximum top horizontal relative displacement for considered earthquake loadings. 


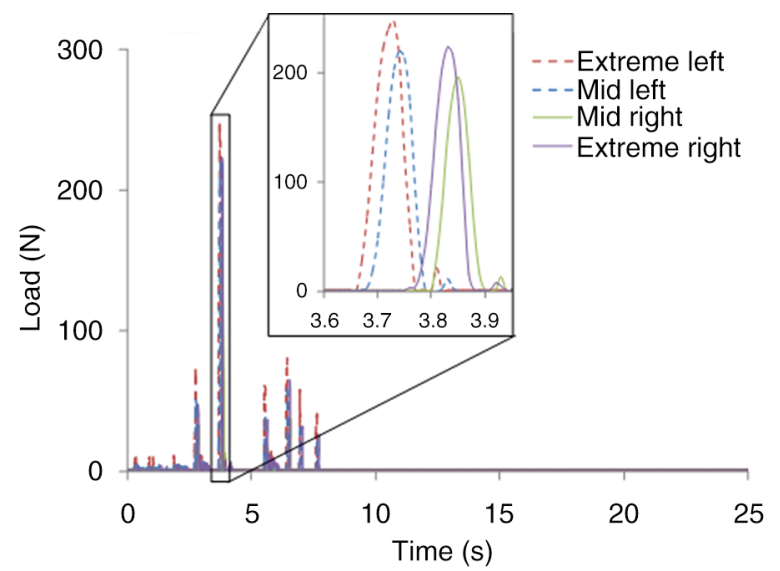

FiguRE 10. Recorded rope tension during $100 \%$ Kobe 1995 loading.

\subsubsection{Rope tension}

Figure 10 shows the load-time histories for the four ropes recorded during 100\% Kobe 1995 loading. The ropes at the extreme left and right ends are named as extreme left and extreme right, respectively. Similarly, the ropes passing through middle block are named as mid left and mid right. As expected, the rope tension at extreme left is more than that at mid left, and same is the trend for right side. The lapse in load-time histories for the left and right ropes (shown in dotted and full lines, respectively in enlarged view) is somewhat similar to that of block uplift. It can be noted that the rope tension started first as compared to the block uplift for the left and right sides. For the small jerks, only rope tension is activated and no block uplift is observed (compare time histories in Figures 10 and 7). Maximum recorded rope tension is around $250 \mathrm{~N}$, which in terms of stress is only $0.25 \mathrm{MPa}$. It may be noted that, in case of collapse (although not observed), the additional stress due to self-weight of blocks would be around 0.5 MPa per rope. The tensile stress of rope up to point A in Figure 3 is somewhat within elastic range. At this point, the stress is around $5 \mathrm{MPa}$. Therefore, the effectiveness of the rope is only $5 \%$ (with respect to tensile stress at point A in Figure 3) in the conducted tests. There is possibly some room for optimization of the rope dimensions which can be considered in future.

Figure 11 shows the maximum rope tension at selected locations for the applied earthquake loadings. These are non-linear with respect to the incremental loadings. The tension in ropes increases considerably after $40 \%$ of the respective seismic loading. It may also be noted that the rope tension at the left side
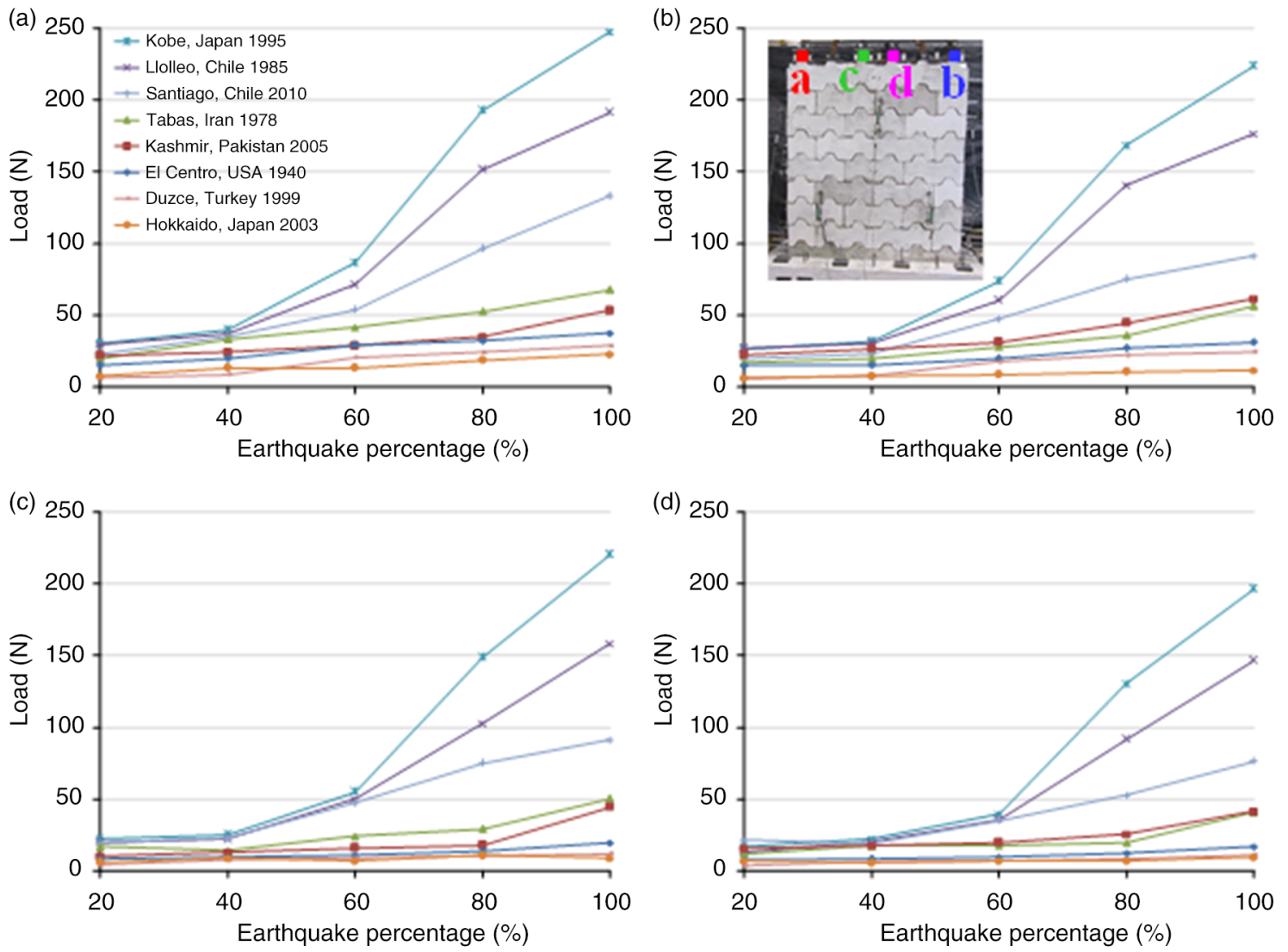

FIGURE 11. Maximum rope tension for considered earthquake loadings. 
is more than that at right side for all loadings except the Kashmir one. This is also observed in case of block uplift.

\section{CONCLUSIONS}

A new approach to construct economical earthquake-resistant houses is considered. To evaluate its effectiveness, a scaled wallette is tested under the different earthquake loadings. The mortar-free wallette consists of newly developed interlocking blocks and coconut-fibre rope reinforcement. Coconut fibre reinforced concrete (CFRC) is used for casting interlocking blocks. CFRC is prepared with $5 \mathrm{~cm}$ long coconut fibres and 1\% content by mass of concrete materials. No mass is put at wallette top and earthquake loadings are scaled because of limitation of shake table. The response of wallette is determined in terms of induced acceleration, block uplift, maximum top relative-displacement and rope tension. The concept of unique interlocking and use of fibre reinforced concrete seems to be helpful. The utilization of rope reinforcement is important to limit the lateral displacement of structure to some extent. No damage is observed either in blocks or rope under any earthquake loading. This might be due to difference of structure and earthquake frequencies.

Following conclusions can be drawn from the conducted study:

- Generally, induced acceleration is increased by $8 \%-18 \%$ for the considered earthquake loadings.

- Negligible uplift is observed because of tight interlocking, thus there is no cracking in CFRC blocks.

- As expected, more uplift is observed at the lower part of the wallette.

- The measured tension at exterior ropes is more. Only $5 \%$ of rope tensile strength of elastic range is being utilized.

- The block uplift, top horizontal relative displacement and rope tension is not only dependent on PGA, but on combined earthquake characteristics like ground displacement, frequency and PGA.

This progressing work is one of the initial efforts towards exploring the behaviour of the deemed technology. The full-scale wall with mass at top should be investigated for better understanding of its seismic performance. At this stage, it can be claimed with confidence (based on above study) that the presented concept of construction can surely help in the development of cheap and safe houses in seismic prone regions. Although this study is unable to clearly identify/verify the behaviour of the wallette as predicted, it has opened the new horizons for future research in achieving the overall goal.

\section{ACKNOWLEDGEMENTS}

The authors would like to thank all persons/organizations who helped throughout this research. The careful review and constructive suggestions by the anonymous reviewers are gratefully acknowledged.

\section{REFERENCES}

1. Munshi, J. (2009) A low-cost housing option in seismic regions. In: Proceedings of the structures songress - don't sess with structural engineers: expanding our role, ASCE. 2741-2750. http://dx.doi.org/10.1061/41031(341)300.

2. Aziz, M.A.; Paramasivam, P.; Lee, S.L. (1984) Concrete reinforced with natural fibres. New Reinf. Concr. 1, 106-140.

3. Baruah, P; Talukdar, S. (2007) A comparative study of compressive, flexural, tensile and shear strength of concrete with fibres of different origins. Indian Concr. J. 81 [7], 17-24. http://www.icjonline.com/main_july2007.htm.

4. Sen, T.; Reddy, H.N.J. (2011) Application of Sisal, Coir and Jute Natural Composites in Structural Upgradation. Int. J. Innov. Manage. Technol. 2 [3], 186-191. http://ijimt.org/ papers/129-M533.pdf.

5. Asasutjarit C.; Hirunlabh J.; Khedari J.; Charoenvai S.; Zeghmati B.; Shin, U.C. (2007) Development of coconut coir-based lightweight cement board. Constr. Build. Mater. 21 [2], 277-288. http://dx.doi.org/10.1016/j.conbuildmat. 2005.08.028.

6. Paramasivam, P.; Nathan, G.K.; Das-Gupta, N.C. (1984) Coconut fibre reinforced corrugated slabs. Int. J. Cem. Compos. Lightweight Concr. 6 [1], 19-27. http://dx.doi.org/ 10.1016/0262-5075(84)90056-3.

7. Ramakrishna, G.; Sundararajan, T. (2005) Impact strength of a few natural fibre reinforced cement mortar slabs: A comparative study. Cem. Concr. Comp. 27 [5], 547-553. http://dx.doi.org/10.1016/j.cemconcomp.2004.09.006.

8. Ramakrishna, G.; Sundararajan, T. (2005) Studies on the durability of natural fibres and the effect of corroded fibres on the strength of mortar. Cem. Concr. Comp. 27 [5], 575-82. http://dx.doi.org/10.1016/j.cemconcomp. 2004.09.008.

9. Gunasekaran, K.; Kumar, P.S.; Lakshmipathy, M. (2011) Mechanical and bond properties of coconut shell concrete. Constr. Build. Mater. 25 [1], 92-98. http://dx.doi.org/10.1016/ j.conbuildmat.2010.06.053.

10. Munawar, S.S.; Umemura, K.; Kawai, S. (2007) Characterization of the morphological, physical, and mechanical properties of seven non-wood plant fibre bundles. J. Wood Sci. 53 [2], 108-113. http://dx.doi.org/10.1007/s10086-0060836-x.

11. Satyanarayana, K.G.; Sukumaran, K.; Mukherjee, P.S.; Pavithran, C.; Pillai, S.G.K. (1990) Natural fibre-polymer composites. Cem. Concr. Comp. 12 [2], 117-136. http://dx.doi. org/10.1016/0958-9465(90)90049-4

12. Saravanan, R.; Sivaraja, M. (2012) Durability studies on coir reinforced bio-composite concrete panel. Eur. J. Sci. Res. 81 [2], 220-30. http://www.linknovate.com/publication/ durability-studies-on-coir-reinforced-bio-composite-concretepanel-2322913/.

13. Mani, P.; Satyanarayana, K.G. (1990) Effects of the surface treatments of lignocellulosic fibres on their debonding stress. J. Adhes. Sci. Technol. 4 [1], 17-24. http://dx.doi.org/ 10.1163/156856190X00036.

14. John, V.M.; Cincotto, C.; Agopyan, V.; Oliveira, C.T.A. (2005) Durability of slag mortar reinforced with coconut fibre. Cem. Conc. Compos. 27 [5], 565-74. http://dx.doi.org/10.1016/ j.cemconcomp.2004.09.007.

15. Thanoon, W.A.; Jaafar, M.S.; Noorzaei, J.; Kadir, M.R.A.; Fares, S. (2007) Structural behaviour of mortar-less interlocking masonry system under eccentric compressive loads. Adv. Struct. Eng. 10 [1], 11-24. http://dx.doi.org/ $10.1260 / 136943307780150832$. 
16. Turek, M.; Ventura, C.E.; Kuan S. (2007) In-plane shake table testing of GFRP-strengthened concrete masonry walls. Earthq. Spectra. 23 [1], 223-237. http://dx.doi.org/10.1193/ 1.2429564

17. Anand, K.B.; Ramamurthy, K. (2000) Development and performance evaluation of interlocking-block masonry. J. Arch. Engg. 6 [2], 45-51. http://dx.doi.org/10.1061/(ASCE) 1076-0431(2000)6:2(45).

18. Anand, K.B.; Ramamurthy, K. (2003) Laboratory-based productivity study on alternative masonry systems. J. Constr. Engg. Manage. 129 [3], 237-242. http://dx.doi.org/10.1061/ (ASCE)0733-9364(2003)129:3(237).

19. Jafaar, M.S.; Thanoon, W.A.; Najm, A.M.S.; Abdulkadir, M.R.; Ali, A.B.A. (2006) Strength correlation between individual block, prism, and basic wall panel for load bearing interlocking mortarless hollow block masonry. Constr. Build. Mater. 20, 492-98. http://dx.doi.org/10.1016/j.conbuildmat. 2005.01.046.

20. Nazar, M.E.; Sinha, S.N. (2007) Fatigue Behaviour of interlocking grouted stabilised mud-fly ash brick masonry. Int. J. Fatigue. 29, 953-61. http://dx.doi.org/10.1016/j.ijfatigue. 2006.07.018

21. Dedek, K.P.; Claude, M.A.M.; Kumaran, G.S. (2012) Feasibility study of low cost concrete products as an appropriate: alternative construction material in the Rwandan construction industry. Adv. Res. Mater. 367, 55-62. http:// dx.doi.org/10.4028/www.scientific.net/AMR.367.55.

22. Smith, E. (2010) Interlocking stabilised soil blocks: Appropriate technology that doesn't cost the earth. The Structural Engineer. 88 [15/16], 25-29.

23. Uygunoglu, T.; Topcu, I.B.; Gencel, O.; Brostow, W. (2012) The effect of fly ash content and types of aggregates on the properties of pre-fabricated concrete interlocking blocks (PCIBs). Constr. Build. Mater. 30, 180-187. http://dx.doi. org/10.1016/j.conbuildmat.2011.12.020.
24. Thanoon, W.A.; Jaafar, M.S.; Kadir, M.R.A.; Ali, A.B.A.; Trikha, D.N.; Najm, A.M.S. (2004) Development of an innovative interlocking load bearing hollow block system in Malaysia. Constr. Build. Mater. 18, 445-454. http://dx.doi. org/10.1016/j.conbuildmat.2004.03.013.

25. Ali, M.; Liu, A.; Sou, H.; Chouw, N. (2012) Mechanical and dynamic properties of coconut fibre reinforced concrete. Constr. Build. Mater. 30, 814-825. http://dx.doi.org/10.1016/j. conbuildmat 2011.12.068.

26. NZS 3112: Part 2. Tests relating to the determination of strength of concrete. 1986.

27. Libre, N.A.; Shekarchi, M.; Mahoutian, M.; Soroushian, P. (2011) Mechanical properties of hybrid fiber reinforced lightweight aggregate concrete made with natural pumice. Constr. Build. Mater. 25 [5], 2458-64. http://dx.doi.org/10.1016/j. conbuildmat.2010.11.058

28. Richardson, A.E.; Conventry, K.; Landless, L. (2010) Synthetic and steel fibres in concrete with regard to equal toughness. Struct.l Surv. 28 [5], 355-369. doi: http://dx.doi. org/10.1108/02630801011089155.

29. Ali, M.; Chouw, N. (2013) Experimental investigations on coconut-fibre rope tensile strength and pullout from coconut fibre reinforced concrete. Constr. Build. Mater. 41, 681-90. http://dx.doi.org/10.1016/j.conbuildmat.2012. 12.052 .

30. Ali, M. Gultom, R.J.; Chouw, N. (2012) Capacity of innovative interlocking blocks under monotonic loading. Constr: Build. Mater. 37, 812-21. http://dx.doi.org/10.1016/j. conbuildmat.2012.08.002

31. Chan, R.; Bindiganavile, V. (2010) Toughness of fibre reinforced hydraulic lime mortar. Part 1, quasi-static response. Mater. Struct. 43, 1435-1444. http://dx.doi.org/10.1617/ s11527-010-9598-4. 